\section{An investigation on the effects of micro-parameters on the strength properties of rock}

Rudarsko-geološko-naftni zbornik

(The Mining-Geology-Petroleum Engineering Bulletin) UDC: 624.121

DOI: 10.17794/rgn.2021.1.9

Review scientific paper

\author{
Behzad Jafari Mohammadabadi'; Kourosh Shahriar ${ }^{2}$; Hossein Jalalifar'; Kaveh Ahangari' \\ ${ }^{1}$ Department of Mining Engineering, Science and Research Branch, Islamic Azad University, Tehran, Iran. \\ ${ }^{2}$ Department of Mining and Metallurgy Engineering, Amirkabir University of Technology, Tehran, Iran. \\ ${ }^{3}$ Department of Petroleum Engineering, Shahid Bahonar University of Kerman, Kerman, Iran.
}

\begin{abstract}
Rocks are formed from particles and the interaction between those particles controls the behaviour of a rock's mechanical properties. Since it is very important to conduct extensive studies about the relationship between the micro-parameters and macro-parameters of rock, this paper investigates the effects of some micro-parameters on strength properties and the behaviour of cracks in rock. This is carried out by using numerical simulation of an extensive series of Uniaxial Compressive Strength (UCS) and Brazilian Tensile Strength (BTS) tests. The micro-parameters included the particles' contact modulus, the contact stiffness ratio, bond cohesion, bond tensile strength, the friction coefficient and the friction angle, and the mechanical properties of chromite rock have been considered as base values of the investigation. Based on the obtained results, it was found that the most important micro-parameters on the behaviour of rock in the compressive state are bond cohesion, bond tensile strength, and the friction coefficient. Also, the bond tensile strength showed the largest effect under tensile conditions. The micro-parameter of bond tensile strength increased the rock tensile strength (up to 5 times), minimized destructive cracks and increased the corresponding strain (almost 2.5 times) during critical stress.
\end{abstract}

\title{
Keywords:
}

Micro-parameter; Rock; Crack; Bond Strength; Uniaxial Compressive Strength (UCS); Brazilian Tensile Strength (BTS); Destructive Crack.

\section{Introduction}

One of the most important factors that affects the behaviour of rocks is their mechanical properties, such as compressive and tensile properties. These properties, which play a dominant role in the mechanism of rock failure, usually attract special attention in rock engineering projects. The behaviour of micro-cracks is another critical factor that is highly regarded. Crack density and propagation show a significant impact on the behaviour and strength properties of rocks. Therefore, any research that helps to gain a better understanding of the behaviour of these mechanical properties is essential. On the other hand, the mechanical behaviour of rock materials is controlled by the grain aggregate and the cementation (bond) between the grains (Delenne et al., 2011; Gao and Kang, 2017; Bahaaddini and Rahimi, 2018; Bahaaddini et al., 2019). Although a few researchers have studied the relations of these mechanical properties of rocks (Huang, 1999; Yang et al., 2006; Xu et al., 2016; Bahaaddini and Rahimi, 2018; Yari and Bagherpour, 2018a; Yari and Bagherpour, 2018b; Yari et al., 2019; Khoshouei et al., 2020), more studies are required to

Corresponding author: Hossein Jalalifar

Jalalifar@uk.ac.ir obtain a comprehensive understanding of these relationships.

In this paper, using numerical simulation of UCS and BTS tests, the effects of micro-parameters on the tensile and compressive strengths of rock are investigated. In addition, the effects of micro-parameters on the behaviour of micro-cracks have been studied in both tests. Since continuum methods cannot effectively reproduce the failure process due to their intrinsic limitations, Particle Code 2D (PFC-2D) has been used for the simulation process, which is a software based on the Discrete Element Method (DEM).

\section{A brief introduction to DEM}

Since Cundall (1971) first proposed DEM for geomechanics applications, it has been proven that DEM is a very powerful method to represent the mechanical behaviour of granular materials (Yang et al., 2006). DEM is essentially a Lagrangian (mesh-free) technique where each individual particle is treated separately and the inter-particle contact forces are calculated on the basis of simple mechanical models such as springs, dashpots, and frictional sliders (Cundall and Strack, 1979). 
The advantage of using DEM-based models is that the underlying physics are clearly resolved and the models are inherently discontinuous and heterogeneous. DEM models are very powerful in the sense that they capture the behaviour of many different types of materials with little or no changes in the model parameters.

In DEM, a granular material is modeled as a collection of separate particles. The particles can take any shape, but for simplicity they are commonly assumed to be perfectly spherical (see Figure. 1). The forces acting on a typical particle in a system consist of body forces as well as forces arising at the contacts with neighbouring particles. The equations of motion for a typical particle in the system are then simply given by Newton's second law of motion (Equations 1 and 2):

$$
\begin{gathered}
m_{p} \dot{V}_{p}=m_{p} f_{g}+\sum_{c} f_{c} \\
I_{p} \dot{\omega}_{p}=\sum_{c} r_{c} \times f_{c}
\end{gathered}
$$

Where:

$V_{p}$ - Translational velocity vector $(\mathrm{m} / \mathrm{s})$. A superposed dot indicates a time derivative.

$\omega_{p}$ - Rotational velocity vector $\left(\mathrm{s}^{-1}\right)$.

$m_{p}$ - Particle mass $(\mathrm{kg})$.

$I_{p}^{p}$ - Particle moment of inertia $\left(\mathrm{mm}^{4}\right)$.

$f_{g}^{p}-$ Gravitational vector $\left(\mathrm{kg} \cdot \mathrm{ms}^{-2}\right)$.

$\stackrel{g}{f}$ - Inter-particle force at contact $\left(\mathrm{kg} \mathrm{m}^{-1} \mathrm{~s}^{-1}\right) \cdot c=$ $1 ; 2 ; \ldots$.

$r_{c}$ - Vector connecting the center of the particle to the location of contact $(\mathrm{mm})$.

\section{Material and methods}

In this research, an extensive series of experimental tests were carried out and then a numerical model was calibrated with the obtained experimental results. Numerical investigations were conducted using Particle PFC2D. This code is among the most widely used DEM- based commercial software, and has been used successfully in a variety of engineering applications such as the simulation of intact rocks (Cui et al., 2019; Potyondy and Cundall, 2004; Akram and Sharrock, 2010), rock cutting and indentation (Kaitkay, 2002; Lei and Kaitkay, 2002; Huang, 1999), underground rock support (Tannant and Wang, 2002), rock joints and jointed rock masses (Bahaaddini, 2017; Bahaaddini et al., 2013; Bahaaddini et al., 2014; Bahaaddini et al., 2016; Yang and Huang, 2018; Deisman et al., 2010; Jiang et al., 2018; Mas Ivars et al., 2011; Asadi et al., 2012).

The main advantage of PFC2D is that there is no need for pre-defined complex empirical constitutive relations, and they have been replaced with simpler particle contact logic without requiring plasticity rules (Bahrani et al., 2011). Another significant advantage of $P F C 2 D$ is that it can simulate a fracture mechanism from crack initiation, propagation, to coalescence explicitly by bond breakage without any special crack-criteria (Zhang and Stead, 2014).

In PFC2D, rock is represented as a dense packing of grains cemented by contacts, which simulate the interaction behaviour between grains ( $\mathrm{Xu}$ et al., 2016). The three main bonding approaches, namely Contact Bond (CB), Parallel Bond (PB) and Flat-Joint (FJ) models, have been proposed for a simulation of the cementation between particles in PFC2D code (Bahaaddini et al., 2019). Due to its ability to reproduce the mechanical behaviour of rock materials under different loading conditions (Bahaaddini et al., 2019), the FJ model has been adopted for numerical modelling in the current study. This model was proposed by Potyondy (2012), with the aim of considering the polygonal grain structure of particles, to fix the intrinsic problems that have been raised in the standard PB model, and it has been implemented in both PFC2D and PFC3D (Itasca Consulting Group, 2015).

Before performing an analysis, it is necessary to determine the base values of the micro-parameters. This

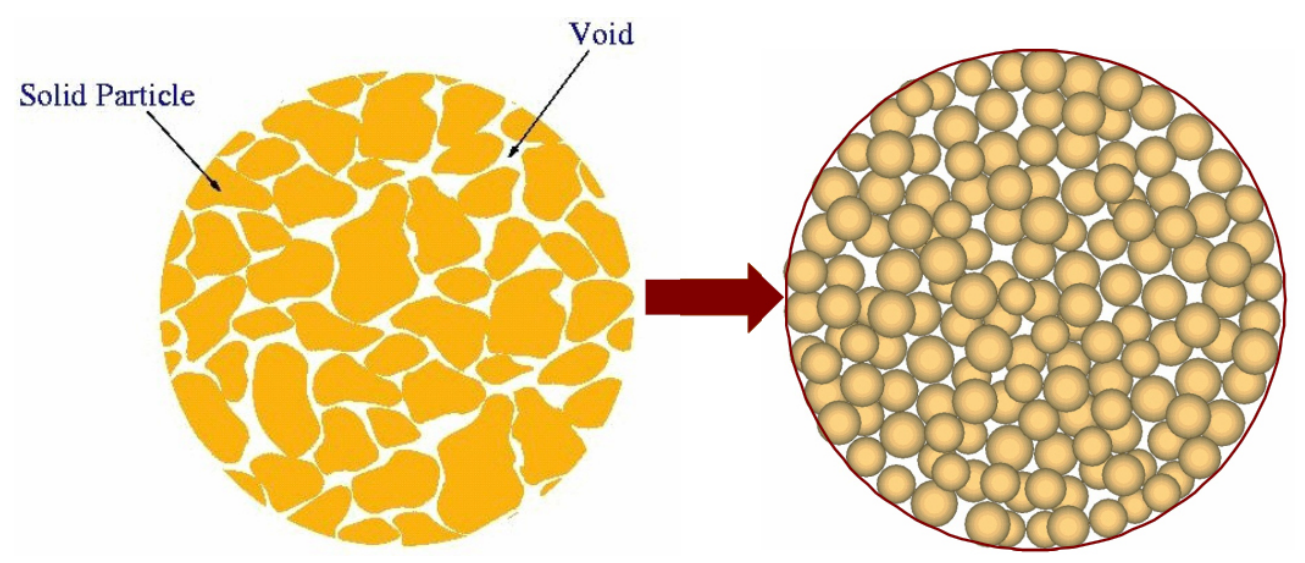

Figure 1: Modeling actual granular soils. (left) as a collection of spheres (right) in Discrete Element Method (El Shamy 2007). 

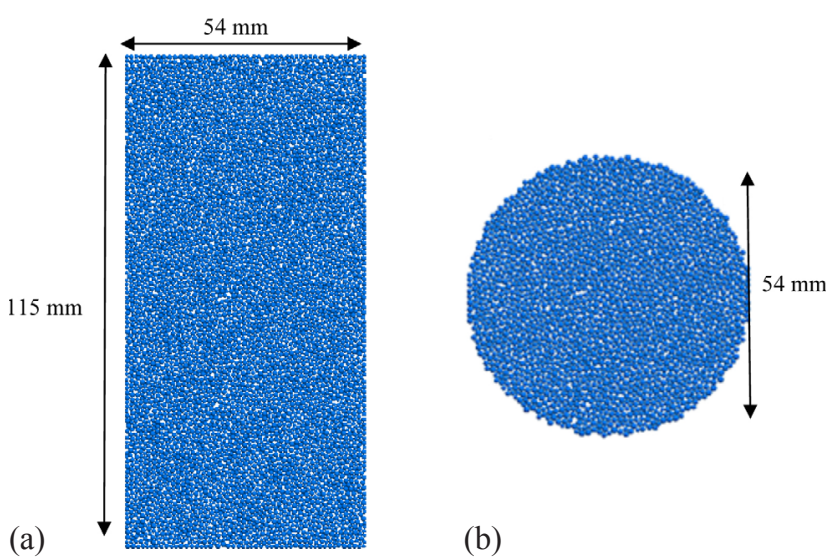

Figure 2: Cross-section of PFC 2D models (a): in UCS tests (b): in BTS tests.

Table 1. Base values of the investigated micro-parameters.

\begin{tabular}{|l|l|l|l|l|}
\hline \multirow{2}{*}{ Property } & \multirow{2}{*}{ Base value } & \multicolumn{2}{|l|}{$\begin{array}{l}\text { Range values } \\
\text { for study }\end{array}$} & \multirow{2}{*}{ Unit } \\
\cline { 3 - 4 } & & Low & High & \\
\hline Density & 5700 & --- & --- & $\left(\mathrm{kg} / \mathrm{m}^{3}\right)$ \\
\hline Bonded fraction & 0.76 & --- & --- & --- \\
\hline Ec & 5.4 & 2 & 10 & $(\mathrm{GPa})$ \\
\hline $\mathrm{K}_{\mathrm{n}} / \mathrm{K}_{\mathrm{s}}$ & 1.8 & 1 & 3 & --- \\
\hline Friction coefficient & 0.5 & 0.1 & 1 & --- \\
\hline Cohesion & 13.3 & 10 & 25 & $(\mathrm{MPa})$ \\
\hline Cohesion std & 1.33 & --- & --- & $(\mathrm{MPa})$ \\
\hline Tensile strength & 6.6 & 5 & 20 & $(\mathrm{MPa})$ \\
\hline Tensile strength std & 0.66 & --- & --- & $(\mathrm{MPa})$ \\
\hline Friction angle & 30 & 10 & 50 & Degree \\
\hline
\end{tabular}

can usually be done by using a calibration process with regard to the macroscopic mechanical properties.

To obtain the base values of the micro-parameters, a calibration process is performed on the experimental data of granular chromite rock samples from the Faryab mine in the southeast of Kerman, Iran. The calibration process of the micro-properties of particles and bonds is carried out by comparing uniaxial tests results in both numerical models and laboratory tests, which is commonly performed by undertaking uniaxial compression tests (Bahaaddini et al., 2019).

In this operation, which is an iterative process (Bahaaddini et al., 2013b), the elastic modulus is calibrated first which depends on "the particle and bond modulus ( $\mathrm{E}_{\mathrm{C}}$ and $\overline{\mathrm{E}}_{C}$ )" and "particle and bond normal/shear stiffness $\left(K_{n} / K_{s}\right.$ and $\left.K^{-n} / K^{-s}\right)$ ". Then $v$ is calibrated in an iterative process with the first step which is controlled by the ratio of normal to shear rigidity in particles and bonds $\left(K_{n} / K_{s}\right.$ and $\left.K^{-n} / K^{-s}\right)$,. Finally, UCS is calibrated which is affected by the bond strength properties. The calibrated values of micro-parameter of particles and bonds are given in Table 1.
For numerical models, the specimen sizes are determined with regards to the types of each test and in accordance with the ISRM recommendations (UCS: diameter $54 \mathrm{~mm}$ and height $115 \mathrm{~mm}$ - BTS: diameter $54 \mathrm{~mm}$ and height $27 \mathrm{~mm}$ ) (Bieniawski and Bernede 1979; Bieniawski and Hawkes 1978). In both types of tests, the particle dimensions follow the normal distribution and are based on the minimum particle radius $\left(r_{\min }=0.45\right.$ $\mathrm{mm})$ and the maximum radius to minimum radius ratio $\left(r_{\max } / r_{\min }=1.5\right)$. Also, UCS and BTS specimens contain 5658 and 2096 particles, respectively (see Figure 2).

\section{Results and discussion}

As mentioned earlier, the aim of this paper is to investigate the effects of micro-parameters on strength properties and micro-crack behaviour of rock materials. In the current study, the effects of six factors from simulated samples including the particle contact modulus $(\mathrm{Ec})$, the contact stiffness ratio $(\mathrm{Kn} / \mathrm{Ks})$, bond cohesion, bond tensile strength, the friction coefficient and the friction angle have been analysed. These aspects of the model results are discussed in sequence in the following sections.

\subsection{Compressive Strength}

The numerical results of UCS tests have been used to study the effect of micro-parameters on the compressive strength of rock. In this research, five models of UCS testing were performed for each micro-parameter. The examining procedure is that during the investigation of each micro-parameter, all micro-parameters are selected to be the same as those in Table 1 . Then, the investigated parameter is varied from a low value to a high value (as displayed in Table 1). Finally, the effects on the compressive strength are studied. The effects of these parameters on UCS tests are demonstrated in Figure 3. Based on the conducted tests, the following results were obtained:

The micro-parameters of particles' contact modulus and friction angle have no obvious effects (see Figures 3a and $\mathbf{f}$ ), and the contact stiffness ratio has very little effect on compressive strength (see Figure 3d). As the bond tensile strength increases, the compressive strength of a specimen increases (the amount of compressive strength increased from $20 \mathrm{MPa}$ to $28 \mathrm{MPa}$ ). However, after a certain amount, the effect of this micro-parameter becomes very small (see Figure 3b). An increase in the amount of bond cohesion and the friction coefficient significantly increases the amount of compressive strength (see Figures $3 \mathbf{c}$ and $\mathbf{e}$ ). The amount of compressive strength increased by $10 \mathrm{MPa}$ and $14 \mathrm{MPa}$ for bond cohesion and friction coefficient, respectively. Also, the efficiency of these micro-parameters decreases after exceeding a certain amount, but they still have a significant effect on the compressive strength. 


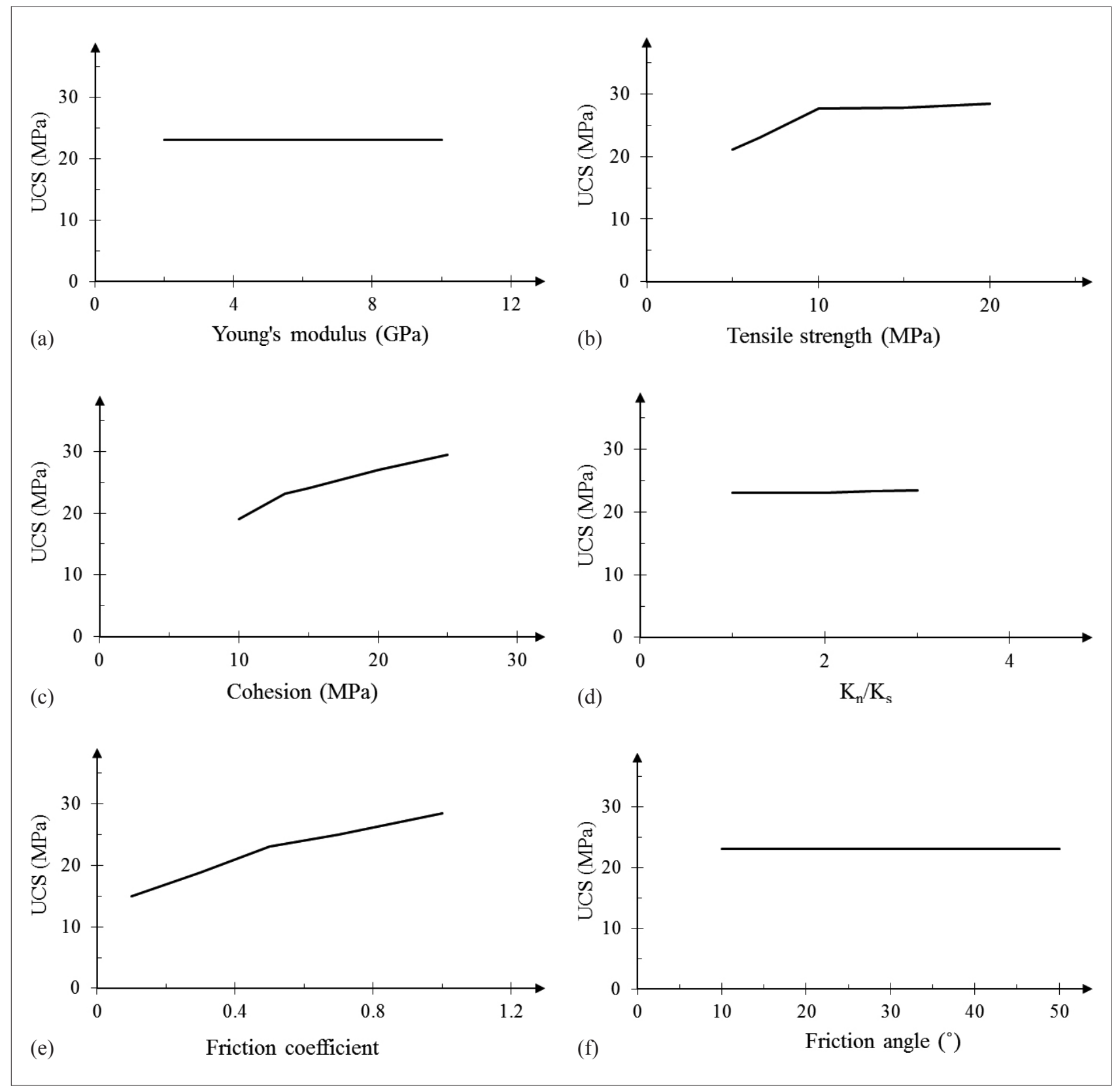

Figure 3: The effect of micro-parameters on compressive strength in UCS tests: (a) particle contact modulus, (b) bond tensile strength, (c) bond cohesion, (d) contact stiffness ratio, (e) friction coefficient and (f) friction angle.

\subsection{Tensile strength}

In order to study the effect of the investigated microparameters on tensile strength, the numerical results of BTS tests were studied. Five BTS tests were simulated in PFC2D for each micro-parameter. The results of these simulations are shown in Figure 4. Based on these results, it can be seen that the micro-parameters of the particle contact modulus, the contact stiffness ratio, bond cohesion, the bond friction coefficient and the friction angle have no obvious effect on the tensile rock strength (see Figures 4a, c, d, e and f). However, the bond tensile strength affects the sample tensile strength. So, increasing this micro-parameter increased the tensile strength up to 5 times (see Figure $\mathbf{4 b}$ ).

\subsection{Micro-cracks behaviour}

To investigate the effects of micro-parameters on the behaviour of micro-cracks, crack density and corresponding strain at critical (destructive) stresses have been studied in both UCS and BTS tests. Four models of UCS and BTS tests were simulated for each micro-parameter, and the applied procedure was the same as the procedure performed in the above sections. The results of these studies are demonstrated in Figures 5 and $\mathbf{6}$.

Based on the results of UCS tests, it was observed that the amount of crack density at critical stress was increased with an increase in the values of the particle contact modulus (up to 2600 cracks), the contact stiffness 


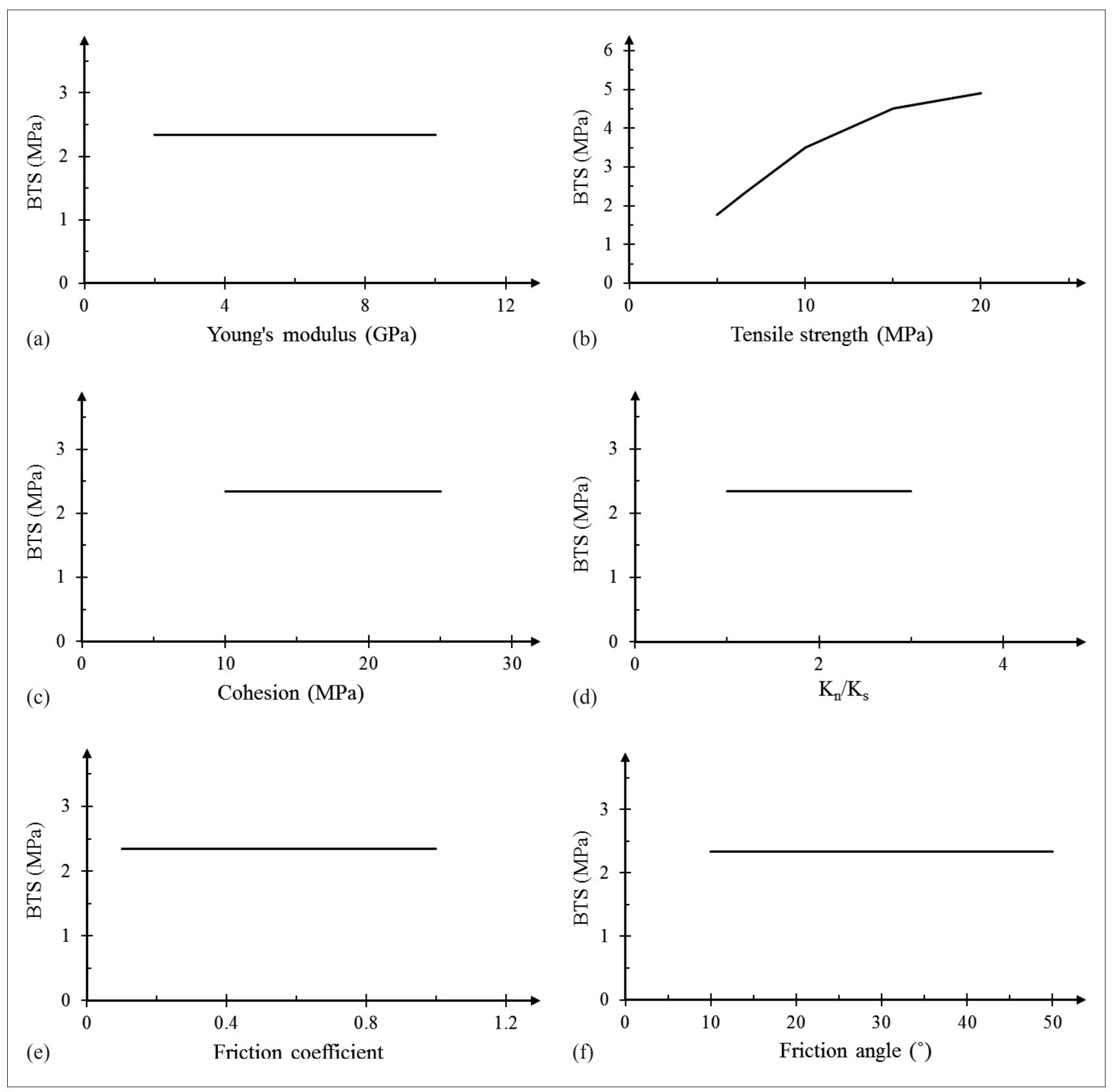

Figure 4. The effects of micro-parameters on tensile strength in BTS tests: (a) particle contact modulus, (b) bond tensile strength, (c) bond cohesion, (d) contact stiffness ratio, (e) friction coefficient and (f) friction angle.

ratio (up to 3000 cracks) and the friction coefficient (up to 2350 cracks) (see Figures 5a, d and e).

The crack density decreased by increasing the amount of bond cohesion (decreased to 320 cracks) and bond tensile strength (decreased to 850 cracks). However, these effects are much lower in the case of bond cohesion (see Figures $\mathbf{5 b}$ and $\mathbf{c}$ ). In addition, with an increase in the bond tensile strength, the contact stiffness ratio, the friction coefficient and decreasing the particle contact modulus and bond cohesion, the corresponding strain increased (see Figures 5a-e). The friction angle also had very little effect on these properties (see Figure 5f).

According to the results of BTS tests, it can be observed that with an increase in the values of bond tensile strength, bond cohesion and the friction coefficient, the crack density is reduced. However, these variations appeared to be low in the parameters of bond cohesion and the friction coefficient (see Figures $6 \mathbf{b}$, $\mathbf{c}$ and e). Increasing the value of particle contact modulus has increased the density of cracks. However, the contact stiffness ratio and friction angle have not shown a significant effect on crack density (see Figures 6a, $\mathbf{d}$ and f). A micro-parameter that has the greatest impact on the corresponding strain is bond tensile strength (see Figure 6b), since increasing this parameter increased the corresponding strain from $0.002 \%$ to $0.005 \%$.

Also, the particle contact modulus, the contact stiffness ratio, the friction coefficient and the friction angle 


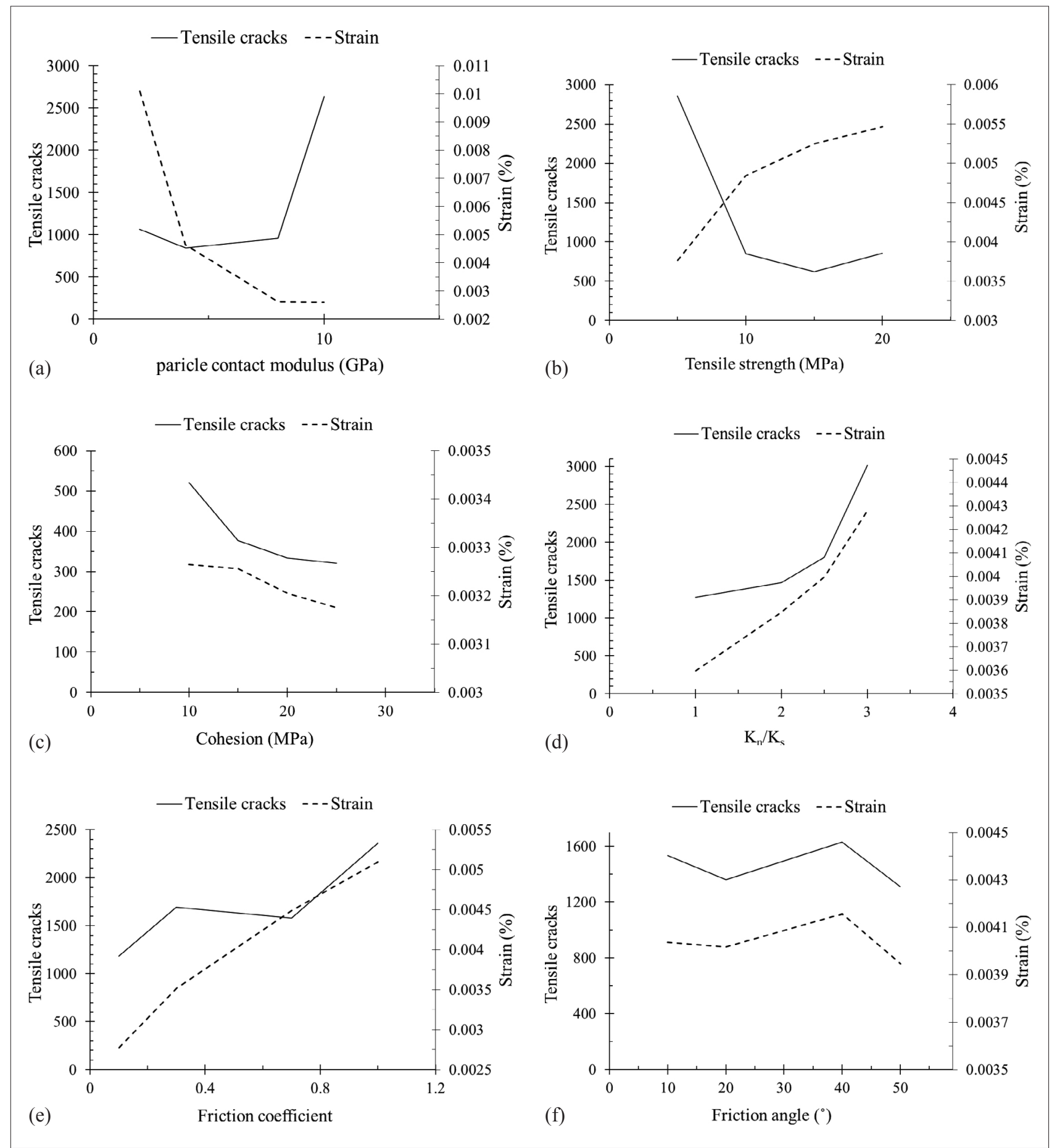

Figure 5: The effects of micro-parameters on crack density in UCS tests: (a) particle contact modulus, (b) bond tensile strength, (c) bond cohesion, (d) contact stiffness ratio, (e) friction coefficient and (f) friction angle.

have shown a slight effect on the corresponding strain, but they are not considerable (see Figures 6a and c-f).

\section{Conclusion}

In this paper, using numerical simulations of UCS and BTS tests in the Discrete Element Method, the effects of micro-parameters of rock grains on the compressive strength, tensile strength and micro-crack behaviour were investigated. The most important results of this study can be summarized as follows:

The micro-parameters that are very important to increase the compressive strength of the rock are bond cohesion, friction coefficient and bond tensile strength. However, special attention is needed in the selection of these micro-parameters, as a little change in the values of these micro-parameters severely affects the other properties of the rock. Increasing some of them may lead 


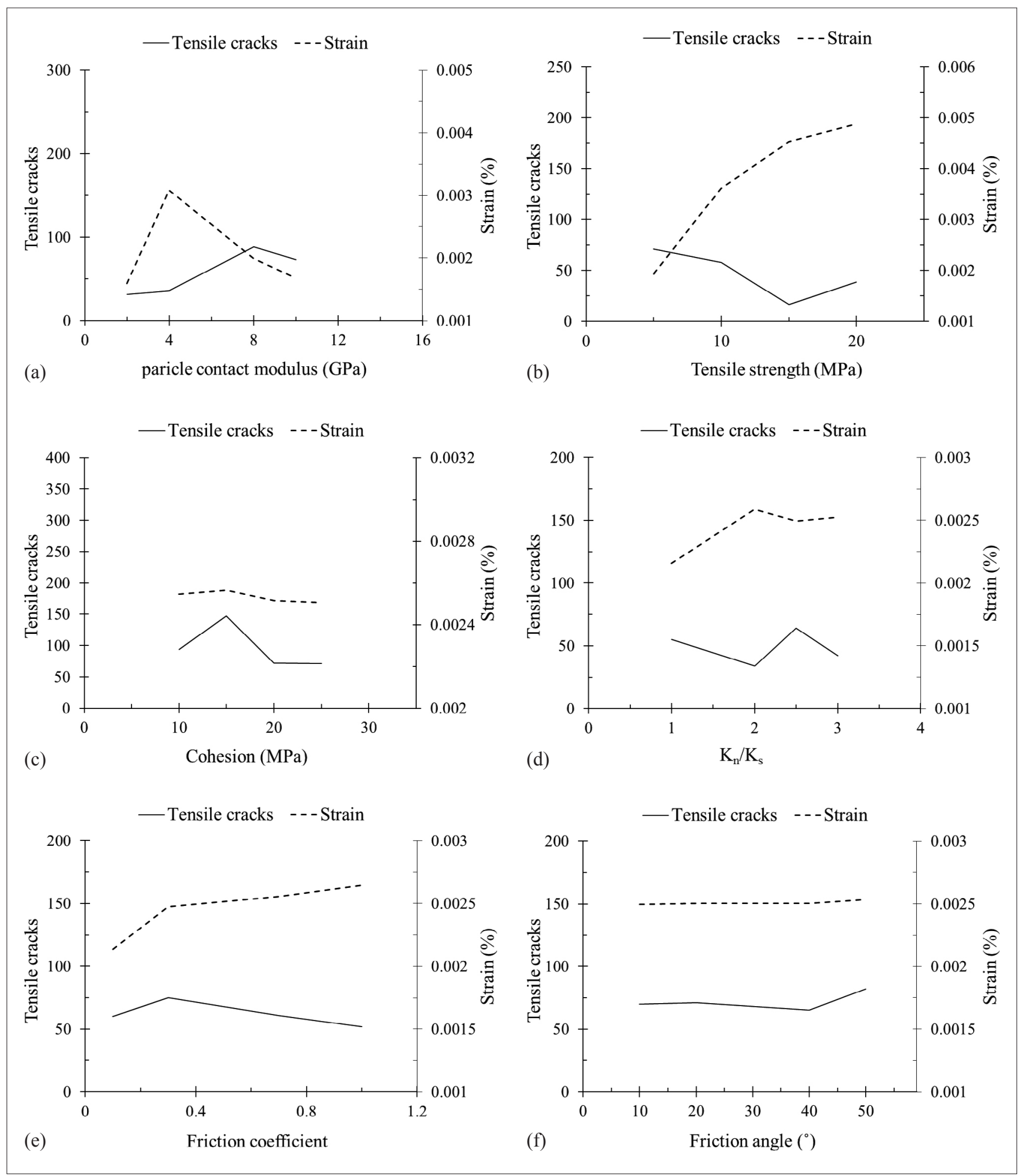

Figure 6: The effects of micro-parameters on crack density in BTS tests: (a) particle contact modulus, (b) bond tensile strength, (c) bond cohesion, (d) contact stiffness ratio, (e) friction coefficient and (f) friction angle.

to a reduction of deformability or an increase in the number of destructive cracks.

In the case of tensile strength, the most effective micro-parameter was bond tensile strength. The amount of this micro-parameter is also very important and effective in increasing deformability and reducing destructive cracks.
Moreover, although micro-parameters such as particle contact modulus and stiffness ratio do not have a significant effect on the amount of strength, they are very important in the deformation and number of destructive cracks and should be considered in geo-engineering designs. 


\section{Reference}

Akram, M. S., \& Sharrock, G. B. (2010). Physical and numerical investigation of a cemented granular assembly of steel spheres. International Journal for Numerical and Analytical Methods in Geomechanics, 34,18, 1896-1934. doi:10.1002/nag.885.

Asadi, M. S., Rasouli, V., \& Barla, G. (2012). A Bonded Particle Model Simulation of Shear Strength and Asperity Degradation for Rough Rock Fractures. Rock Mechanics and Rock Engineering, 45, 5, 649-675. doi:10.1007/s00603012-0231-4.

Bahaaddini, M. (2017). Effect of Boundary Condition on the Shear Behaviour of Rock Joints in the Direct Shear Test. Rock Mechanics and Rock Engineering, 50, 5, 1141-1155. doi:10.1007/s00603-016-1157-z.

Bahaaddini, M., Hagan, P., Mitra, R., \& Hebblewhite, B. (2013a). Numerical investigation of asperity degradation in the direct shear test of rock joints. Eurock. Edited by M. Kwasniewski and D. Lydzba. Taylor \& Francis Group, Poland, 391-397.

Bahaaddini, M., Hagan, P., Mitra, R., \& Hebblewhite, B. K. (2016). Numerical Study of the Mechanical Behavior of Nonpersistent Jointed Rock Masses. International Journal of Geomechanics, 16, 1, 04015035. doi:10.1061/(ASCE) GM.1943-5622.0000510.

Bahaaddini, M., Hagan, P. C., Mitra, R., \& Hebblewhite, B. K. (2014). Scale effect on the shear behaviour of rock joints based on a numerical study. Engineering Geology, 181, 212223. doi:https://doi.org/10.1016/j.enggeo.2014.07.018.

Bahaaddini, M., \& Rahimi, M. (2018). Distinct element modelling of the mechanical behaviour of intact rocks using voronoi tessellation model. International Journal of Mining and Geo-Engineering, 52, 1, 61-68.

Bahaaddini, M., Sharrock, G., \& Hebblewhite, B. K. (2013b). Numerical investigation of the effect of joint geometrical parameters on the mechanical properties of a non-persistent jointed rock mass under uniaxial compression. Computers and Geotechnics, 49, 206-225. doi:https://doi. org/10.1016/j.compgeo.2012.10.012.

Bahaaddini, M., Sheikhpourkhani, A. M., \& Mansouri, H. (2019). Flat-joint model to reproduce the mechanical behaviour of intact rocks. European Journal of Environmental and Civil Engineering, 1-22.

Bahrani, N., Valley, B., Kaiser, P., \& Pierce, M. (2011) 'Evaluation of PFC2D grain-based model for simulation of confinement-dependent rock strength degradation and failure processes' 45th US Rock Mechanics/Geomechanics Symposium. American Rock Mechanics Association.

Bieniawski, Z., \& Bernede, M. 16 (1979) 'Suggested methods for determining the uniaxial compressive strength and deformability of rock materials: Part 1 . Suggested method for determining deformability of rock materials in uniaxial compression' International Journal of Rock Mechanics and Mining Sciences \& Geomechanics Abstracts. Elsevier, pp. 138-140 2 .

Bieniawski, Z., \& Hawkes, I. (1978) 'International-Societyfor-Rock-Mechanics-Commission-on-Standardization-of-
Laboratory-and-Field-tests-suggested methods for determining tensile-strength of rock materials'.

Cui, Z., Sheng, Q., Leng, X., \& Ma, Y. (2019). Investigation of the long-term strength of Jinping marble rocks with experimental and numerical approaches. Bulletin of Engineering Geology and the Environment, 78, 2, 877-882. doi:10.1007/s10064-017-1132-2.

Cundall, P., \& Strack, O. (1979). A discrete numerical model for granular assemblies. geotechnique, 29, 1, 47-65.

Cundall, P. A. (1971) 'A computer model for simulating progressive, large-scale movement in blocky rock system' Proceedings of the International Symposium on Rock Mechanics, 1971.

Deisman, N., Mas Ivars, D., Darcel, C., \& Chalaturnyk, R. J. (2010). Empirical and numerical approaches for geomechanical characterization of coal seam reservoirs. International Journal of Coal Geology, 82, 3, 204-212. doi:https:// doi.org/10.1016/j.coal.2009.11.003.

Delenne, J. Y., SouliÃđC, F., El Youssoufi, M. S., \& Radjai, F. (2011). Compressive strength of an unsaturated granular material during cementation. Powder Technology, 208, 2, 308-311. doi:https://doi.org/10.1016/j.powtec.2010.08.021.

El Shamy, U. (2007). DEM-Based Computational Lab for Geotechnical Engineering Education. Educational Activities in Geotechnical Engineering, pp. 1-10.

Gao, F., \& Kang, H. (2017). Grain-based discrete-element modeling study on the effects of cementation on the mechanical behavior of low-porosity brittle rocks. International Journal of Geomechanics, 17, 9, 04017061.

Huang, H. (1999). Discrete element modeling of tool-rock interaction [Ph. D. Thesis]. Minneapolis, MN: University of Minnesota.

Itasca Consulting Group, I. (2015) 'PFC-Particle Flow Code in 2 and 3 Dimensions' 5.0.

Jiang, M., Liao, Y., Wang, H., \& Sun, Y. (2018). Distinct element method analysis of jointed rock fragmentation induced by TBM cutting. European Journal of Environmental and Civil Engineering, 22, sup1, s79-s98. doi:10.1080/ 19648189.2017.1385540.

Kaitkay, P. V. (2002) Modeling of rock cutting using distinct element methods. Kansas State University

Khoshouei, M., Bagherpour, R., Jalalian, M. H., \& Yari, M. (2020). Investigating the acoustic signs of different rock types based on the values of acoustic signal RMS. Rudarsko-geološko-naftni zbornik (The Mining-Geological-Petroleum Bulletin), 35, 3, 29-38.

Lei, S., \& Kaitkay, P. (2002). Micromechanical modeling of rock cutting under pressure boundary conditions using distinct element method. Technical papers-society of manufacturing engineers-all series-.

Mas Ivars, D., Pierce, M. E., Darcel, C., Reyes-Montes, J., Potyondy, D. O., Paul Young, R., et al. (2011). The synthetic rock mass approach for jointed rock mass modelling. International Journal of Rock Mechanics and Mining Sciences, 4, 2, 219-244. doi:https://doi.org/10.1016/j. ijrmms.2010.11.014.

Potyondy, D. (2012) 'A flat-jointed bonded-particle material for hard rock' 46th US rock mechanics/geomechanics symposium. American Rock Mechanics Association. 
Potyondy, D. O., \& Cundall, P. A. (2004). A bonded-particle model for rock. International Journal of Rock Mechanics and Mining Sciences, 41(8), 1329-1364. doi:https://doi. org/10.1016/j.ijrmms.2004.09.011.

Tannant, D. D., \& Wang, C. (2002). Thin rock support liners modeled with particle flow code. Discrete element methods: Numerical modeling of discontinua, pp. 346-352.

Xu, X., Wu, S., Gao, Y., \& Xu, M. (2016). Effects of Microstructure and Micro-parameters on Brazilian Tensile Strength Using Flat-Joint Model. Rock Mechanics and Rock Engineering, 49, 9, 3575-3595. doi:10.1007/s00603016-1021-1.

Yari, M., \& Bagherpour, R. (2018a). Implementing acoustic frequency analysis for development the novel model of determining geomechanical features of igneous rocks using rotary drilling device. Geotechnical and Geological Engineering, 36, 3, 1805-1816.

Yari, M., \& Bagherpour, R. (2018b). Investigating an innovative model for dimensional sedimentary rocks characteri- zation using acoustic frequencies analysis during drilling. Rudarsko-geološko-naftni zbornik (The Mining-Geological-Petroleum Bulletin), 33, 2, 17-25.

Yari, M., Bagherpour, R., \& Khoshouei, M. (2019). Developing a novel model for predicting geomechanical features of carbonate rocks based on acoustic frequency processing during drilling. Bulletin of Engineering Geology and the Environment, 78, 3, 1747-1759.

Yang, B., Jiao, Y., \& Lei, S. (2006). A study on the effects of microparameters on macroproperties for specimens created by bonded particles. Engineering Computations.

Yang, S.-Q., \& Huang, Y.-H. (2018). Failure behaviour of rock-like materials containing two pre-existing unparallel flaws: an insight from particle flow modeling. European Journal of Environmental and Civil Engineering, 22, sup1, s57-s78. doi:10.1080/19648189.2017.1366954.

Zhang, Y., \& Stead, D. (2014). Modelling 3D crack propagation in hard rock pillars using a synthetic rock mass approach. International journal of rock mechanics and mining sciences, 1997, 72, 199-213.

\section{SAŽETAK}

\section{Istraživanje utjecaja mikroparametara na svojstva čvrstoće stijene}

Svaka je stijena stvorena od čestica čijim se međudjelovanjem određuju njezina mehanička svojstva. Budući da je vrlo važno provesti opsežne studije o povezanosti mikroparametara i makroparametara stijene, u ovome su radu istraživani učinci nekih mikroparametara na svojstva čvrstoće i ponašanje pukotina stijene numeričkim simulacijama jednoosne tlačne čvrstoće (UCS) i brazilske vlačne čvrstoće (BTS). Ispitivani mikroparametri uključivali su kontakt čestica, omjer kontaktne krutosti, koheziju veze, vlačnu čvrstoću, koeficijent trenja i kut trenja, a mehanička svojstva stijene bogate kromitom bile su osnovne vrijednosti ispitivanih mikroparametara. Utvrđeno je kako su najvažniji mikroparametri na ponašanje stijene kod tlačenja kohezija veze, vlačna čvrstoća veze i koeficijent trenja. Također, vlačna čvrstoća ima najveći učinak u vlačnim uvjetima. Ovaj mikroparametar povećava vlačnu čvrstoću (do 5 puta), minimalizira destruktivne pukotine i povećava odgovarajuće naprezanje (gotovo 2,5 puta) pri kritičnome naprezanju.

\section{Ključne riječi:}

mikroparametar, stijena, pukotina, snaga veze, jednoosna tlačna čvrstoća, brazilska vlačna čvrstoća, destruktivna pukotina

\section{Author's contribution}

Behzad Jafari Mohammadabadi, Hossein Jalalifar, Kourosh Shahriar and Kaveh Ahangari shared contributions in the numerical and theoretical parts of the paper. 